Article

\title{
Exergy-Based Life Cycle Assessment of Buildings: Case Studies
}

\author{
Martin Nwodo*(i) and Chimay J. Anumba
}

check for updates

Citation: Nwodo, M.; Anumba, C.J. Exergy-Based Life Cycle Assessment of Buildings: Case Studies. Sustainability 2021, 13, 11682 https://doi.org/10.3390/ su132111682

Academic Editors: Elie Azar and Mounir El Asmar

Received: 13 August 2021

Accepted: 10 October 2021

Published: 22 October 2021

Publisher's Note: MDPI stays neutral with regard to jurisdictional claims in published maps and institutional affiliations.

Copyright: (c) 2021 by the authors. Licensee MDPI, Basel, Switzerland. This article is an open access article distributed under the terms and conditions of the Creative Commons Attribution (CC BY) license (https:// creativecommons.org/licenses/by/ $4.0 /)$.
Department of Construction Management, College of Design, Construction and Planning, University of Florida, Gainesville, FL 32611, USA; anumba@ufl.edu

* Correspondence: nwodomartin@ufl.edu

\begin{abstract}
The relevance of exergy to the life cycle assessment (LCA) of buildings has been studied regarding its potential to solve certain challenges in LCA, such as the characterization and valuation, accuracy of resource use, and interpretation and comparison of results. However, this potential has not been properly investigated using case studies. This study develops an exergy-based LCA method and applies it to three case-study buildings to explore its benefits. The results provide evidence that the theoretical benefits of exergy-based LCA as against a conventional LCA can be achieved. These include characterization and valuation benefits, accuracy, and enabling the comparison of environmental impacts. With the results of the exergy-based LCA method in standard metrics, there is now a mechanism for the competitive benchmarking of building sustainability assessments. It is concluded that the exergy-based life cycle assessment method has the potential to solve the characterization and valuation problems in the conventional life-cycle assessment of buildings, with local and global significance.
\end{abstract}

Keywords: life cycle assessment; LCA; exergy; buildings; sustainability

\section{Introduction}

The construction and operation of buildings together contribute to $36 \%$ of the world's energy end-use and close to $40 \%$ of energy-related carbon dioxide emissions [1]. Life cycle assessment (LCA) ascertains the resource inputs and outputs into and out of a product (in this case, a building) system and the potential environmental impacts thereof. The benefits of producing an LCA of buildings have been identified in previous studies and include the assessment of the environmental benefits of new building products, the formulation of environmental policy for buildings and building products, decision support in product and process development, the assignment of environmental "credits" (as a measure of environmental sustainability) to buildings in green building certification and, in some cases, consideration in the evaluation of building design options [2-4]. However, there are challenges when performing a building LCA that limit the realization of its full benefits. The conventional building LCA faces methodological challenges such as the inconsistency in functional units, the difficulty of system boundary definition, choice of allocation method, and accuracy of data sourcing [4]. In addition, major challenges faced in the practical use of the conventional LCA method to assess buildings include, but are not limited to, the difficulty of identifying areas for improvement, subjectivity in results interpretation, and the difficulty when comparing results [5]. There is a need to improve on the conventional LCA method as well as on its use for assessing the LCA of buildings. In life cycle analysis, exergy enables the quantification of the cumulative consumption of resources [6], as well as serving as an indicator of efficient energy and resource use [7,8]. Exergy provides a potential indicator of environmental impact [9] and, thus, can be applied to LCA. Using exergy, the life cycle inventory (LCI) assesses the building as a whole [10]. The benefit of including exergy is especially useful in LCAs of buildings where the LCI details of subprocesses may be lacking. This research demonstrates the application of the exergy concept to the LCA of buildings as an alternative approach, to improve on the limitations of 
the conventional LCA method. The exergy considered in this research is non-flow exergy, to differentiate it from its original purpose as a decision-making thermodynamic tool for engineering systems analysis [11]. This research utilizes fossil fuel as the primary energy source for LCA input and, as a result, only the chemical exergy values of resources are used. Therefore, in this paper, all references to "exergy", unless otherwise noted, refer to non-flow chemical exergy. With that delimitation, and utilizing the primary energy source, exergy can characterize resources in LCA in terms of quality of energy and, thus, can eliminate the need for characterization factors in a conventional LCA. That capacity of exergy improves objectivity in a results comparison of the LCA of products-in this case, buildings. Three case-study buildings are utilized in this research to demonstrate a relative comparison of the potential environmental impacts of the buildings using an exergy-based LCA approach. The following sections include a literature review of the relevance of exergy in LCA, development of the method for an exergy-based LCA, the application of the developed method to case studies and results, a discussion, and our conclusions.

\section{Literature Review: Relevance of Exergy to a Building Life Cycle Assessment}

This section presents a literature review of exergy, broadly, as it relates to other indicators of energy, then in more detail regarding its relevance to building LCAs. The term exergy, like entropy and emergy, is a measure of the quality of energy [12]. Unlike entropy, which measures unavailable energy, exergy quantifies the potential of energy and matter to disperse during their diffusion into their environment [13]. Emergy can be expressed as a function of exergy [14] and is, therefore, considered to be much broader. Following the period of elaboration, which aims to improve conventional LCA [15], exergy in LCA (Figure 1) is conceptually considered to be a more accurate and objective method by which to account for lifecycle resource use $[6,16]$. Some studies have been conducted on the relevance of exergy in LCAs [17] but no study was found that investigated the practical relevance of exergy to building LCA, which is a knowledge gap that this study intends to fill.

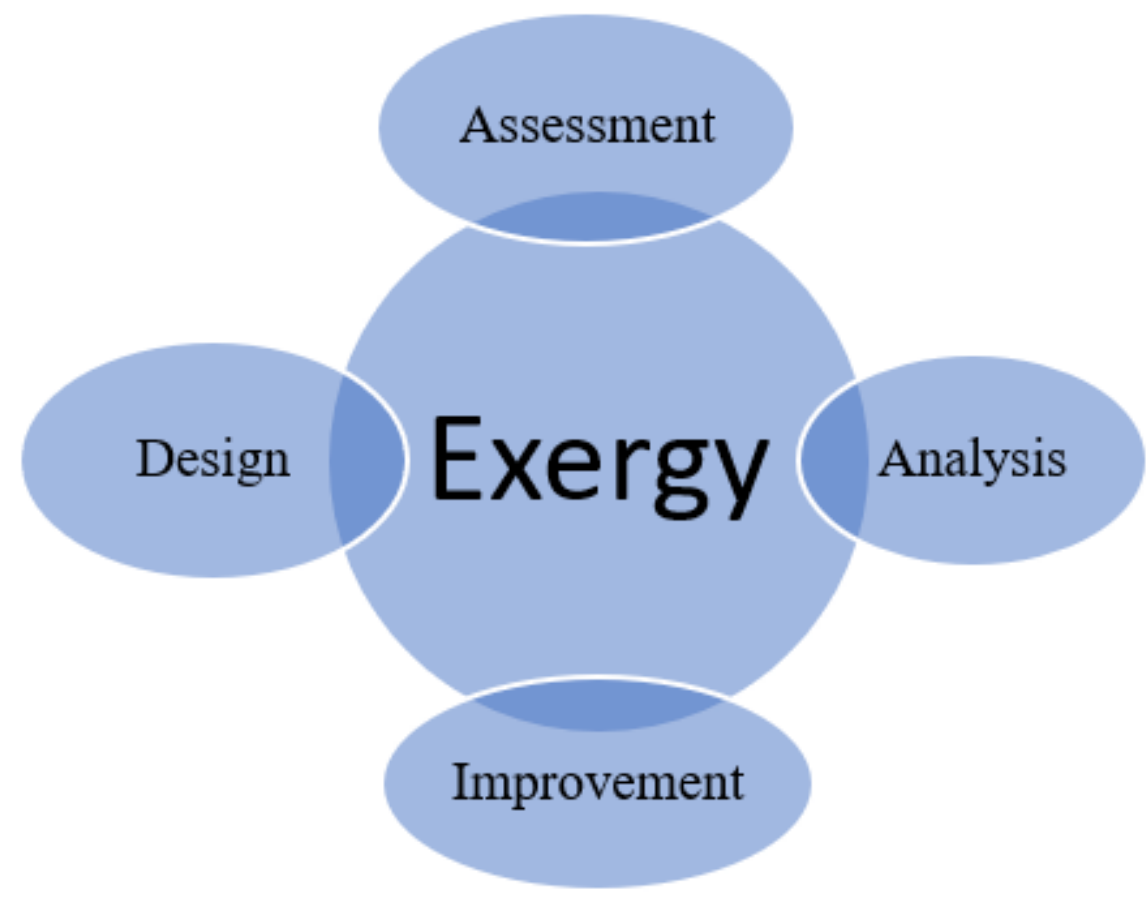

Figure 1. Illustration of key items in exergy [18].

Recently, improvement efforts have been made to address the challenges in building LCA. For example, Švajlenka et al. [19] reported the commercial availability of process databases for material and energy flows to improve on the lack of data for LCA. An analysis 
of state of the art in the integration of LCA with building information modeling (BIM) for data management [20-22] highlights many benefits: the integration of BIM-LCA with environmental product declarations (EPDs) for detailed and accurate data for a life cycle inventory [23]; the integration of building LCA and BIM's standard industry foundation classes (IFC) to reduce access barriers and assessment effort/time [24,25]; the comparison of LCAs of buildings with different material structure alternatives [26]. These advantages are the point of departure for assessing the relevance of an exergy-based LCA of buildings. The conventional LCA method, to date, characterizes each impact category and presents the results uniquely. For example, the global warming potential is characterized and expressed as its $\mathrm{kg}-\mathrm{CO}_{2}$ equivalent, as is the acidification potential, and so on. The main observed problem with such characterization is the difficulty of results comparison. For example, Building Alternative A may have a higher global warming potential value than Building Alternative B but a lower acidification potential value. Additional assumptions will need to be made to compare their environmental impacts. As mentioned previously, exergy can characterize the resources of LCA in terms of quality energy. In that way, exergy characterizes the environmental impact categories as a single objective function, which makes it easier to compare products (in this case, buildings) than with conventional LCA. In this study, the method for an exergy-based LCA of buildings is used because of the following potential advantages:

- An exergy-based LCA method can express environmental impacts as a single objective function, which enables comparison of the results;

- It can identify the unit process or building life cycle phase to be improved;

- An exergy-based LCA method can overcome the resource-use characterization problem found in the conventional LCA method, thereby reducing or eliminating subjectivity when interpreting the results;

- It can measure the exergy losses of the mass of materials, and emissions of buildings, which is essential for the environmental sustainability assessment of buildings;

- An exergy-based method can complement the conventional LCA method, to provide a more in-depth assessment.

\section{Exergy-Based Life Cycle Assessment (Exe-LCA) of Buildings}

\subsection{Development of the Method for Exe-LCA of Buildings}

There are various exergy-based methods, with diverse practical applications. A comparative analysis of the major exergy-based methods was conducted by Nwodo and Anumba [17]. This study utilizes the cumulative exergy demand (CExD), proposed by Szargut et al. [27], as an exergy-based method for the assessment of the case-study buildings used in this study because it is the most commonly applied method to assess environmental impacts [28]. This section describes in detail the elements of the adapted CExD for an ExeLCA of buildings. Three techniques may be used to calculate the CExD for Exe-LCA [27]: (a) process analysis, which traces and evaluates exergy for all the manufacturing processes of a product; (b) balance equations of cumulative exergy demand, which uses a system of equations to express the CExD of final products as a sum of the cumulative exergy of the intermediate products and that of the natural resources extracted directly from the environment; and (c) extension from cumulative energy consumption, which calculates the CExD based on Cumulative Energy Demand (CED). Both techniques (a) and (b) are utilized in this research. For buildings, the CExD can be applied to the following basic elements in the conventional LCA (Figure 2):

- $\quad$ Applied to primary energy demand (PED) to ascertain the primary exergy demand (PExD).

- $\quad$ Applied to material mass (MM) to ascertain material exergy demand (MExD).

- Applied to emission mass (EM) to ascertain the exergy loss of emissions (ExLE). 


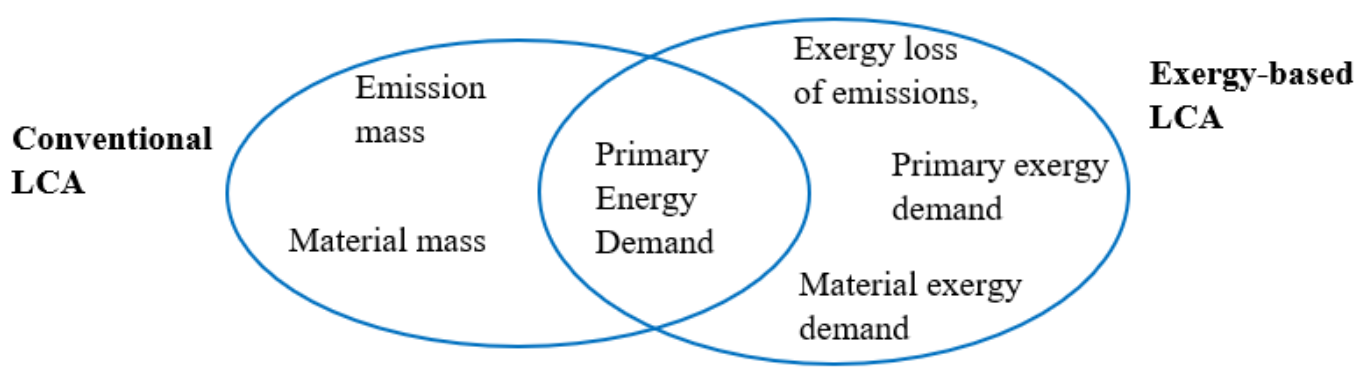

Figure 2. Generic composition of conventional LCA and exergy-based LCA.

\subsubsection{Measure of Exergy of Material Mass, and Energy Demand}

In a conventional LCA, primary energy demand and material mass are referred to as resource use. Unlike the conventional LCA method, the proposed Exe-LCA method expresses primary energy demand and material mass in terms of exergy demands. In this study, life cycle resource use refers to primary energy demand and material mass for the conventional LCA method and refers to primary exergy demand and material exergy demand for the proposed Exe-LCA method.

Primary exergy demand is derived from primary energy demand. Primary energy is the energy embodied in natural resources before being transformed into intermediate and/or end-use energy. Examples of primary energy resources include coal, natural gas, sunlight, wind, rivers, biomass, geothermal, and nuclear energy resource. For combustible energy sources such as fossil fuels, primary energy is calculated based on the calorific value of the fuel and the amount of fuel required to generate a given unit of electricity or heat [29]. For non-combustible energy sources (i.e., renewable energy sources), primary energy is calculated using either primary energy equivalencies or the conversion efficiencies of the renewable energy source.

In this study, the energy sources for the case study buildings are coal and natural gas (fossil fuels). Wang et al. [30] determined that for a given fuel source, the PExD is a product of PED and the gross calorific exergy-to-energy ratio $(\alpha)$ (Equation (1)). In this study, the equation is extended to accommodate two or more fuel sources. When two or more fuel sources are involved, the PExD is a cumulative value of the product of PED, the gross calorific exergy-to-energy ratio $(\alpha)$ and percentage combination $(p)$ for each (i) of a total number (n) of the fuel source (Equation (2)). Gross calorific value is considered appropriate for the exergy-to-energy ratio instead of net calorific value because the former is produced under reversible conditions, which is in accordance with exergy definition, while the latter maintains an irreversible condition.

$$
\begin{gathered}
\text { PExD }=\text { PED } * \alpha * 1 \\
\text { PExD }=\sum_{\mathrm{i}=1}^{\mathrm{n}} \operatorname{PED} * \alpha_{\mathrm{i}} * \mathrm{p}_{\mathrm{i}}
\end{gathered}
$$

Similarly, material exergy demand (MExD) is a derivative of material mass. Material mass, in the conventional LCA of buildings, is a quantity take-off (in $\mathrm{kg}$ ) of the materials in the building model under consideration. MExD, however, goes deeper to measure the material resource depletion equivalence of the material mass. For each building material (e.g., aluminum, brick, concrete, steel, etc.), MExD uses the unit exergy of the building material to estimate the resource depletion (such as chemical elements and ores) that occurred to produce the material. The unit exergy of a material is a cumulative value of the standard unit exergies of the substances that make up the material. The standard unit exergy of a substance is the unit exergy of the substance when the reference environment is composed of air at $298.15 \mathrm{~K}$ of temperature and $101.325 \mathrm{kPa}$ of pressure. Chemical exergy is considered in this study instead of physical exergy or any other type of exergy because chemical exergy depends on the temperature, pressure, and composition of the system, 
while other types of exergy do not consider the composition of the substance. Therefore, chemical exergy evaluation is more holistic than that of the other exergy types. Tables of values for standard chemical exergies of substances are established in the literature [27]. The standard chemical exergy of substances, as expected, is given in $\mathrm{kJ} / \mathrm{mol}$.

Wang et al. [30] stated that the embodied chemical exergy of a material is a product of its chemical exergy and its mass but did not elaborate on how to determine the chemical exergy of a material. This study advanced the equation in Wang et al. [30] to elaborate on how to determine the standard chemical exergy of a material using the standard chemical exergies of the substances that make up the material. Therefore, MExD is a product of material mass and the standard chemical exergy of the material (SCExM) (Equation (3)). The SCExM is a cumulative value of the quotient of standard chemical exergy as the dividend, and molar mass as the divisor for each substance (i), of a total number (n) of the substances that make up the material (Equation (4)).

$$
\begin{aligned}
\text { MExD } & =\text { material mass } * \text { SCExM } \\
\text { SCExM } & =\sum_{\mathrm{i}=1}^{\mathrm{n}} \frac{(\text { SCEx in } \mathrm{kJ} / \mathrm{mol})_{\mathrm{i}}}{(\text { molar mass in } \mathrm{g} / \mathrm{mol})_{\mathrm{i}}}
\end{aligned}
$$

\subsubsection{Measure of Exergy of Life Cycle Emission}

Unlike material exergy demand, which is a function of mass, the exergy of life cycle emissions can be estimated as a function of energy demand, using Equations (5) and (6). It is referred to as the exergy loss of emission (ExLE) in this study. This is simply the exergy that is lost to the environment due to the emission of substances that cause environmental impacts in a building's life cycle. These emitted substances are said to have environmental impact potential because the actual degree of environmental harm that results from the emissions depends on the regional ecosystem conditions and the location of the occurrence. According to Bailey [31], an ecosystem region is a large area with a similar climate where similar biotic and abiotic interactions occur on similar sites. The units of potential environmental impact are in kilograms of the equivalent relative contribution (eq) of an emission that is commonly associated with that form of environmental impact (e.g., $\mathrm{kg} \mathrm{SO}_{2}$-eq for acidification impact potential). In general, ExLE for each (i) of the environmental impact potentials is a product of energy use and the standard chemical exergy of emission (SCExE) (Equation (5)). In turn, the SCExE is calculated as the quotient of molar mass in $\mathrm{g} / \mathrm{mol}$ (i.e., dividend) and the standard chemical exergy in $\mathrm{kJ} / \mathrm{mol}$ (i.e., divisor) (Equation (6)). In this study, Equations (5) and (6) were applied to the five common environmental impact potentials, according to the environmental impact model developed by the US Environmental Protection Agency (EPA) to quantify the environmental impact risk associated with emissions into the environment in the United States.

$$
\begin{aligned}
& \text { ExLE }_{\mathrm{i}}=\text { Energy }_{\text {use }_{\mathrm{i}}} * \mathrm{SCExE}_{\mathrm{i}} \\
& \operatorname{SCExE}_{\mathrm{i}=1}=\frac{\left(\text { molar mass in } \frac{\mathrm{g}}{\mathrm{mol}}\right)_{\mathrm{i}}}{\left(\operatorname{SCEx} \text { in } \frac{\mathrm{kJ}}{\mathrm{mol}}\right)_{\mathrm{i}}}
\end{aligned}
$$

\subsection{Illustration of Exergy-Based LCA Method: Calculation of Standard Chemical Exergy of Emissions, SCExE}

Following Equations (1)-(6), which are mathematical representations of the exergybased LCA method, this section illustrates a typical way by which the values can be obtained. All the Equations are applied fully in the following section of building assessment case studies. This section illustrates the exergy-based method, with the calculation of the standard chemical exergy of the emissions of gases that result in global warming. Global warming potential is caused by the following main emission gases: carbon dioxide, methane, nitrous oxide, and fluorinated gases. The fluorinated gases include CFCs, HFCs, 
HCFCs, perfluorocarbons (PFCs), sulfur hexafluoride $\left(\mathrm{SF}_{6}\right)$, and nitrogen trifluoride $\left(\mathrm{NF}_{3}\right)$. This section illustrates how global warming potential can be estimated, in terms of available energy, from the cumulative exergy demand of the gases using an exergy-based LCA method. The assumptions include that the substances are in a pure state and under standard conditions of temperature (i.e., $298.15 \mathrm{~K}$ ) and pressure (i.e., $1 \mathrm{~atm}$.). The exergy content of a substance can be evaluated as a summation of its Gibbs free energy and its cumulative chemical exergy demand [32,33]. Equation (7) gives a mathematical representation for the evaluation of the standard chemical exergy content for each of the gases.

$$
E x_{g}=\Delta_{g} G^{\circ}+\sum n_{i, g} * E x_{i, g}
$$

Here, Ex $x_{\mathrm{g}}$ is the total exergy content of the gas, $\mathrm{g}$ in $\mathrm{kJ} / \mathrm{mol}, \Delta_{\mathrm{g}} \mathrm{G}^{\circ}$ is the Gibbs free energy of the gas, $\mathrm{g}$ in $\mathrm{kJ} / \mathrm{mol}, \mathrm{n}_{\mathrm{i}, \mathrm{g}}$ is the coefficient of the reactant, $\mathrm{i}$, in the exergy balance of the reaction in the formation of gas, $\mathrm{g} \mathrm{Ex}_{\mathrm{i}, \mathrm{g}}$ is the exergy content of the reactant, $\mathrm{i}$, in the exergy balance of the reaction in the formation of gas, $\mathrm{g}$ in $\mathrm{kJ} / \mathrm{mol}$.

Carbon Dioxide $\left(\mathrm{CO}_{2}\right)$

Balancing equation: $\mathrm{C}_{(\mathrm{s})}+\mathrm{O}_{2(\mathrm{~g})}=\mathrm{CO}_{2(\mathrm{~g})}$

The exergy balance of the reaction of formation is:

$$
\begin{gathered}
\mathrm{Ex}_{\mathrm{CO}_{2}}=\Delta_{\mathrm{CO}_{2}} \mathrm{G}^{\circ}+\left(1 * \mathrm{Ex}_{\mathrm{C}}\right)+\left(1 * \mathrm{Ex}_{\mathrm{O}_{2}}\right)=-394.4+(1 * 410.26)+(1 * 3.97)=19.8 \mathrm{~kJ} / \mathrm{mol} \\
\text { Methane }\left(\mathrm{CH}_{4}\right) \\
\text { Balancing equation: } \mathrm{C}_{(\mathrm{s})}+2 \mathrm{H}_{2(\mathrm{~g})}=\mathrm{CH}_{4(\mathrm{~g})} \\
\text { The exergy balance of the reaction of formation is: } \\
\mathrm{Ex}_{\mathrm{CH}_{4}=\Delta_{\mathrm{CH}_{4}} \mathrm{G}^{\circ}+\left(1 * \mathrm{Ex}_{\mathrm{C}}\right)+\left(2 * \mathrm{Ex}_{\mathrm{H}_{2}}\right)=-50.5+(1 * 410.26)+(2 * 236.09)=831.9 \mathrm{~kJ} / \mathrm{mol}}
\end{gathered}
$$

\section{Nitrous Oxide $\left(\mathrm{N}_{2} \mathrm{O}\right)$}

Balancing equation: $\mathrm{N}_{2(\mathrm{~g})}+0.5 \mathrm{O}_{2(\mathrm{~g})}=\mathrm{N}_{2} \mathrm{O}_{(\mathrm{g})}$

The exergy balance of the reaction of formation is:

$$
\mathrm{Ex}_{\mathrm{N}_{2} \mathrm{O}}=\Delta_{\mathrm{N}_{2} \mathrm{O}} \mathrm{G}^{\circ}+\left(1 * \mathrm{Ex}_{\mathrm{N}_{2}}\right)+\left(0.5 * \mathrm{Ex}_{\mathrm{O}_{2}}\right)=103.7+(1 * 0.72)+(0.5 * 3.97)=106.4 \mathrm{~kJ} / \mathrm{mol}
$$

Trichlorofluoromethane (CFC-11 or $\mathrm{CFCl}_{3}$ )

Balancing equation: $\mathrm{C}_{(\mathrm{s})}+0.5 \mathrm{~F}_{2(\mathrm{~g})}+1.5 \mathrm{Cl}_{2(\mathrm{~g})}=\mathrm{CFCl}_{3(\mathrm{~g})}$

The exergy balance of the reaction of formation is:

$$
\begin{aligned}
\mathrm{Ex}_{\mathrm{CFCl}_{3}} & =\Delta_{\mathrm{CFCl}_{3}} \mathrm{G}^{\circ}+\left(1 * \mathrm{Ex}_{\mathrm{C}}\right)+\left(0.5 * \mathrm{Ex}_{\mathrm{F}_{2}}\right)+\left(1.5 * \mathrm{Ex}_{\mathrm{Cl}_{2}}\right) \\
& =-270.22+(1 * 410.26)+(0.5 * 504.9)+(1.5 * 123.6)=577.9 \mathrm{~kJ} / \mathrm{mol}
\end{aligned}
$$

Difluorodichloromethane (CFC-12 or $\mathrm{CCl}_{2} \mathrm{~F}_{2}$ )

Balancing equation: $\mathrm{C}_{(\mathrm{s})}+\mathrm{Cl}_{2(\mathrm{~g})}+\mathrm{F}_{2(\mathrm{~g})}=\mathrm{CCl}_{2} \mathrm{~F}_{2(\mathrm{~g})}$

The exergy balance of the reaction of formation is:

$$
\begin{aligned}
& \mathrm{Ex}_{\mathrm{CF}_{2} \mathrm{Cl}_{2}}=\Delta_{\mathrm{CF}_{2} \mathrm{Cl}_{2}} \mathrm{G}^{\circ}+\left(1 * \mathrm{Ex}_{\mathrm{C}}\right)+\left(1 * \mathrm{Ex}_{\mathrm{Cl}_{2}}\right)+\left(1 * \mathrm{Ex}_{\mathrm{F}_{2}}\right) \\
& =-439.4+(1 * 410.26)+(1 * 123.6)+(1 * 504.9)=599.4 \mathrm{~kJ} / \mathrm{mol}
\end{aligned}
$$

Trifluoromethane (HFC-23 or $\mathrm{CHF}_{3}$ )

Balancing equation: $\mathrm{C}_{(\mathrm{s})}+0.5 \mathrm{H}_{2(\mathrm{~g})}+1.5 \mathrm{~F}_{2(\mathrm{~g})}=\mathrm{CHF}_{3(\mathrm{~g})}$

The exergy balance of the reaction of formation is:

$$
\begin{aligned}
\mathrm{Ex}_{\mathrm{CHF}_{3}} & =\Delta_{\mathrm{CHF}_{3}} \mathrm{G}^{\circ}+\left(1 * \mathrm{Ex}_{\mathrm{C}}\right)+\left(0.5 * \mathrm{Ex}_{\mathrm{H}_{2}}\right)+\left(1.5 * \mathrm{Ex}_{\mathrm{F}_{2}}\right) \\
& =-663.08+(1 * 410.26)+(0.5 * 236.09)+(1.5 * 504.9)=622.6 \mathrm{~kJ} / \mathrm{mol}
\end{aligned}
$$

Difluorochloromethane (HCFC-22 or $\mathrm{CHClF}_{2}$ )

Balancing equation: $\mathrm{C}_{(\mathrm{s})}+0.5 \mathrm{H}_{2(\mathrm{~g})}+0.5 \mathrm{Cl}_{2(\mathrm{~g})}+1 \mathrm{~F}_{2(\mathrm{~g})}=\mathrm{CHClF}_{2(\mathrm{~g})}$ 
The exergy balance of the reaction of formation is:

$$
\begin{aligned}
\mathrm{Ex}_{\mathrm{CHClF}_{2}} & =\Delta_{\mathrm{CHClF}_{2}} \mathrm{G}^{\circ}+\left(1 * \mathrm{Ex}_{\mathrm{C}}\right)+\left(0.5 * \mathrm{Ex}_{\mathrm{H}_{2}}\right)+\left(0.5 * \mathrm{Ex}_{\mathrm{Cl}_{2}}\right)+\left(1 * \mathrm{Ex}_{\mathrm{F}_{2}}\right) \\
& =-450.47+(1 * 410.26)+(0.5 * 236.09)+(0.5 * 123.6)+(1 * 504.9) \\
& =644.5 \mathrm{~kJ} / \mathrm{mol}
\end{aligned}
$$

Hexafluoroethane (PFC-116 or $\mathrm{C}_{2} F_{6}$ )

Balancing equation: $2 \mathrm{C}_{(\mathrm{s})}+3 \mathrm{~F}_{2(\mathrm{~g})}=\mathrm{C}_{2} \mathrm{~F}_{6}(\mathrm{~g})$

The exergy balance of the reaction of formation is:

$$
\begin{aligned}
\operatorname{Ex}_{\mathrm{C}_{2} \mathrm{~F}_{6}} & =\Delta_{\mathrm{C}_{2} \mathrm{~F}_{6}} \mathrm{G}^{\circ}+\left(2 * \mathrm{Ex}_{\mathrm{C}}\right)+\left(3 * \mathrm{Ex}_{\mathrm{F}_{2}}\right)=-1257.38+(2 * 410.26)+(3 * 504.9) \\
& =1077.8 \mathrm{~kJ} / \mathrm{mol}
\end{aligned}
$$

Nitrogen trifluoride $\left(\mathrm{NF}_{3}\right)$

Balancing equation: $0.5 \mathrm{~N}_{2(\mathrm{~g})}+1.5 \mathrm{~F}_{2(\mathrm{~g})}=\mathrm{NF}_{3(\mathrm{~g})}$

The exergy balance of the reaction of formation is:

$$
\begin{aligned}
\mathrm{Ex}_{\mathrm{NF}_{3}} & =\Delta_{\mathrm{NF}_{3}} \mathrm{G}^{\circ}+\left(0.5 * \mathrm{Ex}_{\mathrm{N}_{2}}\right)+\left(1.5 * \mathrm{Ex}_{\mathrm{F}_{2}}\right)=-90.6+(0.5 * 0.72)+(1.5 * 504.9) \\
& =667.1 \mathrm{~kJ} / \mathrm{mol}
\end{aligned}
$$

Sulfur hexafluoride $\left(S F_{6}\right)$

Balancing equation: $\mathrm{S}_{(\mathrm{s})}+3 \mathrm{~F}_{2(\mathrm{~g})}=\mathrm{SF}_{6}(\mathrm{~g})$

The exergy balance of the reaction of formation is:

$\mathrm{Ex}_{\mathrm{SF}_{6}}=\Delta_{\mathrm{SF}_{6}} \mathrm{G}^{\circ}+\left(1 * \mathrm{Ex}_{\mathrm{S}}\right)+\left(3 * \mathrm{Ex}_{\mathrm{F}_{2}}\right)=-1396.14+(1 * 609.6)+(3 * 504.9)=728.2 \mathrm{~kJ} / \mathrm{mol}$

Table 1 shows the values of the unit standard chemical exergy of emissions of gases that have global warming potential. Once the energy use in MJ is known, the absolute values of the emission potential of the gases in $\mathrm{kg}$ can be estimated. Similar calculations can be made for other environmental impact categories, and for the standard chemical exergy of materials. The following section presents the application of the exergy-based LCA method to building assessment case studies, in which their energy uses, and material masses, are known.

Table 1. Values of the standard chemical exergy of emissions, SCExE, for GWP gases.

\begin{tabular}{cccc}
\hline Greenhouse Gas & SCExE $(\mathbf{k J} / \mathbf{m o l})$ & Molar Mass $(\mathbf{g} / \mathbf{m o l})$ & SCExE in $\mathbf{~ k g} / \mathbf{M J}$ \\
\hline $\mathrm{CO}_{2}$ & 19.8 & 44.01 & 2.22 \\
\hline $\mathrm{CH}_{4}$ & 831.9 & 16.04 & 0.02 \\
\hline $\mathrm{N}_{2} \mathrm{O}$ & 106.4 & 44.01 & 0.41 \\
\hline $\mathrm{CFC}-11$ & 577.9 & 137.37 & 0.24 \\
\hline $\mathrm{CFC}-12$ & 599.4 & 120.91 & 0.20 \\
\hline $\mathrm{HFC}-23$ & 622.6 & 70.01 & 0.11 \\
\hline $\mathrm{HCFC}-22$ & 644.5 & 86.47 & 0.13 \\
\hline $\mathrm{PFC}-116$ & 1077.8 & 138.01 & 0.13 \\
\hline $\mathrm{NF}_{3}$ & 667.1 & 71.00 & 0.11 \\
\hline $\mathrm{SF}_{6}$ & 728.2 & 146.06 & 0.20 \\
\hline Total for units of global warming potential $(\mathrm{kg} / \mathrm{MJ})$ & & 3.77 \\
\hline
\end{tabular}

\section{Case Studies of Exergy-Based Life Cycle Assessment of Buildings}

\subsection{Choice of Case Study Buildings}

The method for the Exe-LCA of buildings was applied to three case-study buildings (Buildings I-III). The criteria for selection of the case-study buildings included their similar- 
ity in the space's function, size, and last major renovation, in addition to their differences in energy use, year of construction, and building rating system certifications. Another important selection criterion is the availability of their building information models.

Building I (Figure 3A) is a three-story building of about $48,911 \mathrm{ft}^{2}\left(4544 \mathrm{~m}^{2}\right)$ gross area that was completed in 2003 with an average annual electric (coal) and heating (natural gas) demand of 1563 GJ and 2965 GJ, respectively. It is oriented on a north-south axis, while two major facades of the building face in the east and west directions. Due to the implementation of large glazing facades, most parts of the building are lit by daylight throughout the year. Furthermore, recycled content, manufacturing proximity, low toxicity, low maintenance requirements and recyclability were considered when choosing the materials used in the building construction. Building I received an LEED Gold certification from the USGBC.

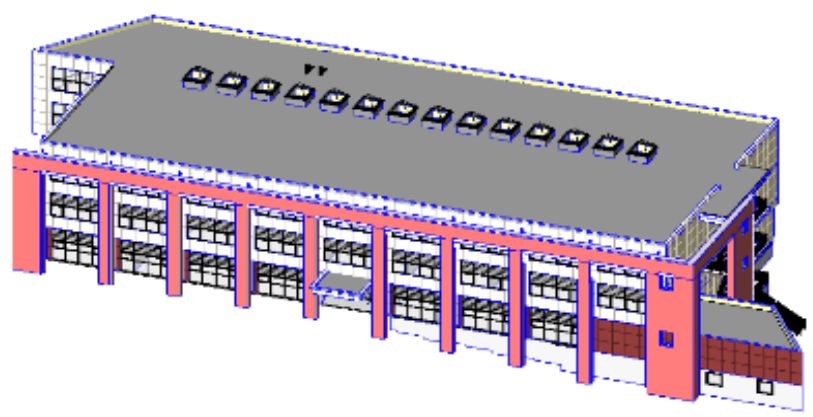

(A)

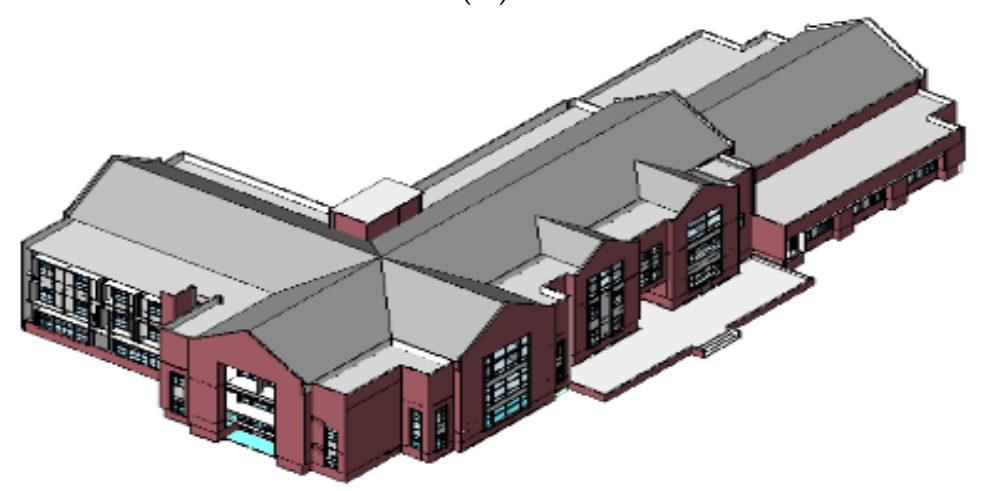

(B)

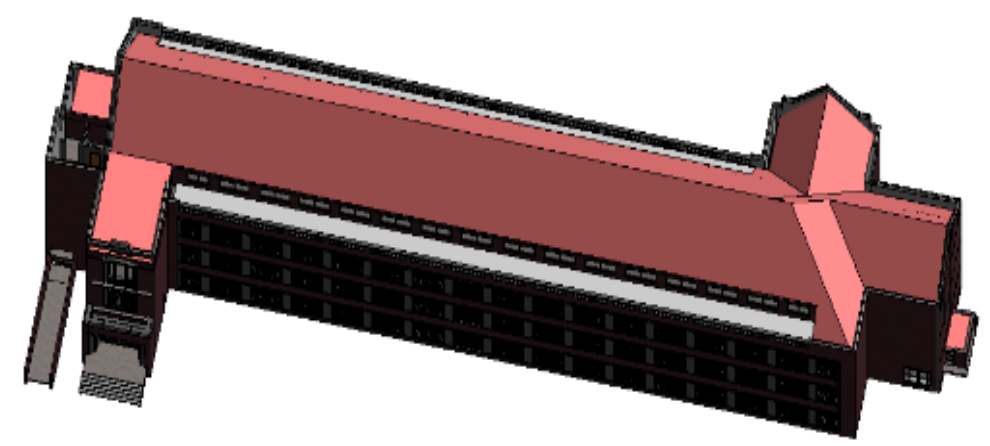

(C)

Figure 3. (A). Building I Revit model. (B). Building II Revit model. (C). Building III Revit model. 
Building II (Figure 3B) is a three-story building with about 45,693 $\mathrm{ft}^{2}\left(4245 \mathrm{~m}^{2}\right)$ gross area that was completed in 2008. with an average annual electric (coal), and heating (natural gas) demand of $1893 \mathrm{GJ}$ and $1306 \mathrm{GJ}$, respectively. It is primarily oriented on an east-west axis, while two major facades of the building face in north and south directions. Among other sustainability features in the building are an atrium, low volatile organic compound materials, lighting, and thermal control. Building II received an LEED Silver certification from the USGBC.

Building III (Figure 3C) is a historic three-story building (including a basement) with about $52,775 \mathrm{ft}^{2}\left(4903 \mathrm{~m}^{2}\right)$ gross area that was completed in 1954 , with an average annual electric (coal), and heating (natural gas) demand of 1731 GJ and 4387 GJ, respectively. It is primarily oriented on an east-west axis, while two major facades of the building face in the north and south directions.

\subsection{Approach to Case Studies}

The primary energy demand (PED) is a function of annual energy use and was assumed to be 1.4 times the average annual energy use for each building case study. The annual energy use is the summation of the average annual electric and heating energy use. The gross calorific exergy-to-energy ratio $(\alpha)$ is constant for coal and natural gas, at 1.03 and 0.94, respectively, as reported by Szargut and Morris [32]. Similarly, the percentages of fuel combinations for coal and natural gas were taken as $31 \%$ and $69 \%$, respectively, according to the 2013 Florida electric power generation figures. Using Equations (1) and (2), the primary exergy demand can then be calculated.

The material exergy demand is a function of material mass. The Revit building information models of the building case studies were created to obtain the masses of the main building materials. The material exergy demand was calculated from the material mass, and the standard material chemical exergy using Equations (3) and (4).

Finally, the environmental impact categories are calculated using Equations (5) and (6) as a function of energy use (exergy loss of emission) and then multiplied by the respective energy use to get an estimate of the absolute quantity.

\section{Results of the Case Study of Buildings}

Results of Exe-LCA for Each Case Study

The results of the application of the exergy-based method to the case-study buildings are presented in Table 2 and in Figures 4-6. The results are discussed in the following section. A table of values for the material exergy demand of the individual main building materials for the three case study buildings can be found in Appendices A-C.

Table 2. Summary of Results of the Case Study Buildings.

\begin{tabular}{cccc}
\hline Exergy-Based LCA Item & Building I & Building II & Building III \\
\hline Annual Primary Exergy Demand (GJ) & $6.1 \times 10^{3}$ & $4.3 \times 10^{3}$ & $8.3 \times 10^{3}$ \\
Total Material Exergy Demand (GJ) & $8.6 \times 10^{3}$ & $8.2 \times 10^{3}$ & $3.4 \times 10^{4}$ \\
Global Warming Potential (kg) & $2.3 \times 10^{7}$ & $1.6 \times 10^{7}$ & $3.1 \times 10^{7}$ \\
Acidification Potential (kg) & $7.0 \times 10^{5}$ & $5.0 \times 10^{5}$ & $1.0 \times 10^{6}$ \\
Eutrophication Potential (kg) & $2.5 \times 10^{6}$ & $1.8 \times 10^{6}$ & $3.4 \times 10^{6}$ \\
Ozone Depletion Potential (kg) & $2.7 \times 10^{6}$ & $1.9 \times 10^{6}$ & $3.6 \times 10^{6}$ \\
Smog Formation Potential (kg) & $1.7 \times 10^{6}$ & $1.2 \times 10^{6}$ & $2.4 \times 10^{6}$ \\
\hline
\end{tabular}




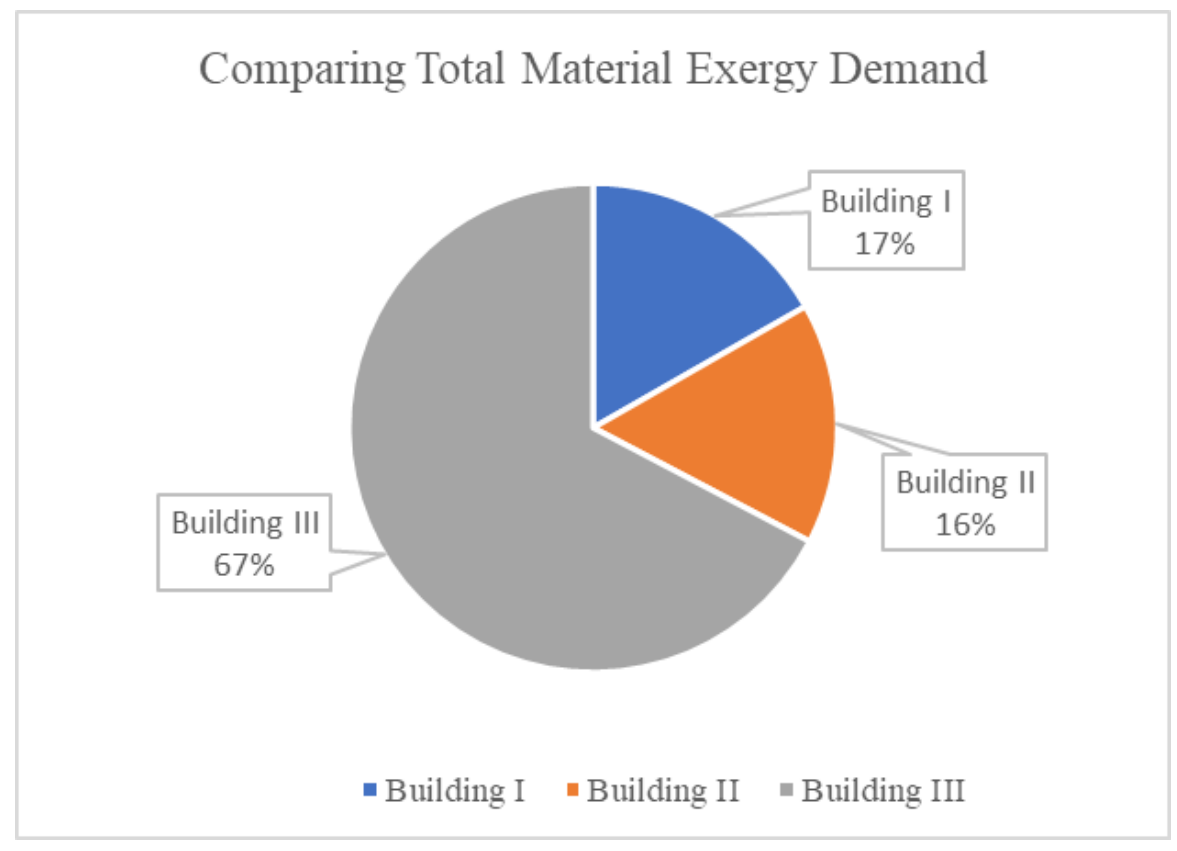

Figure 4. Comparing Material Exergy Demand between Case Study Buildings.

Comparing Total Environmental Impact Potential

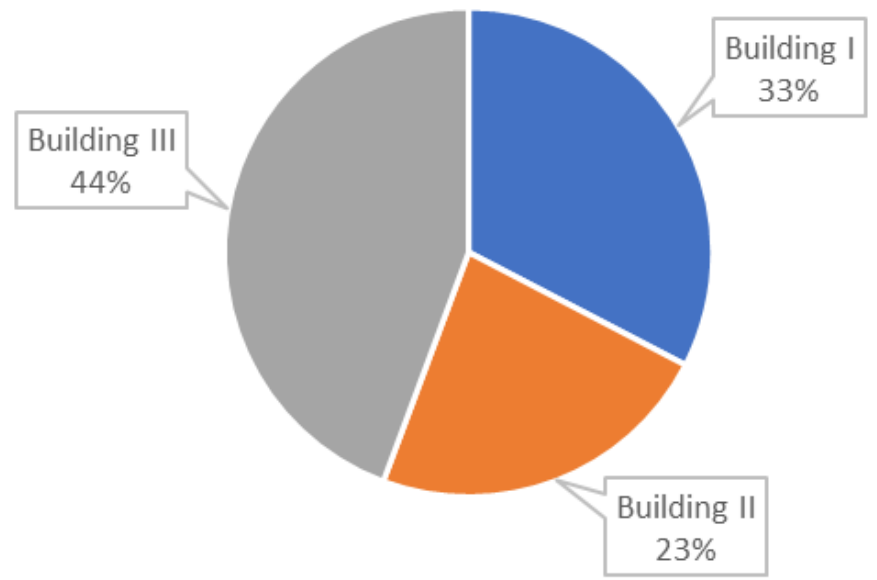

- Building I - Building II - Building III

Figure 5. Comparing total environmental impact potential between case study buildings. 


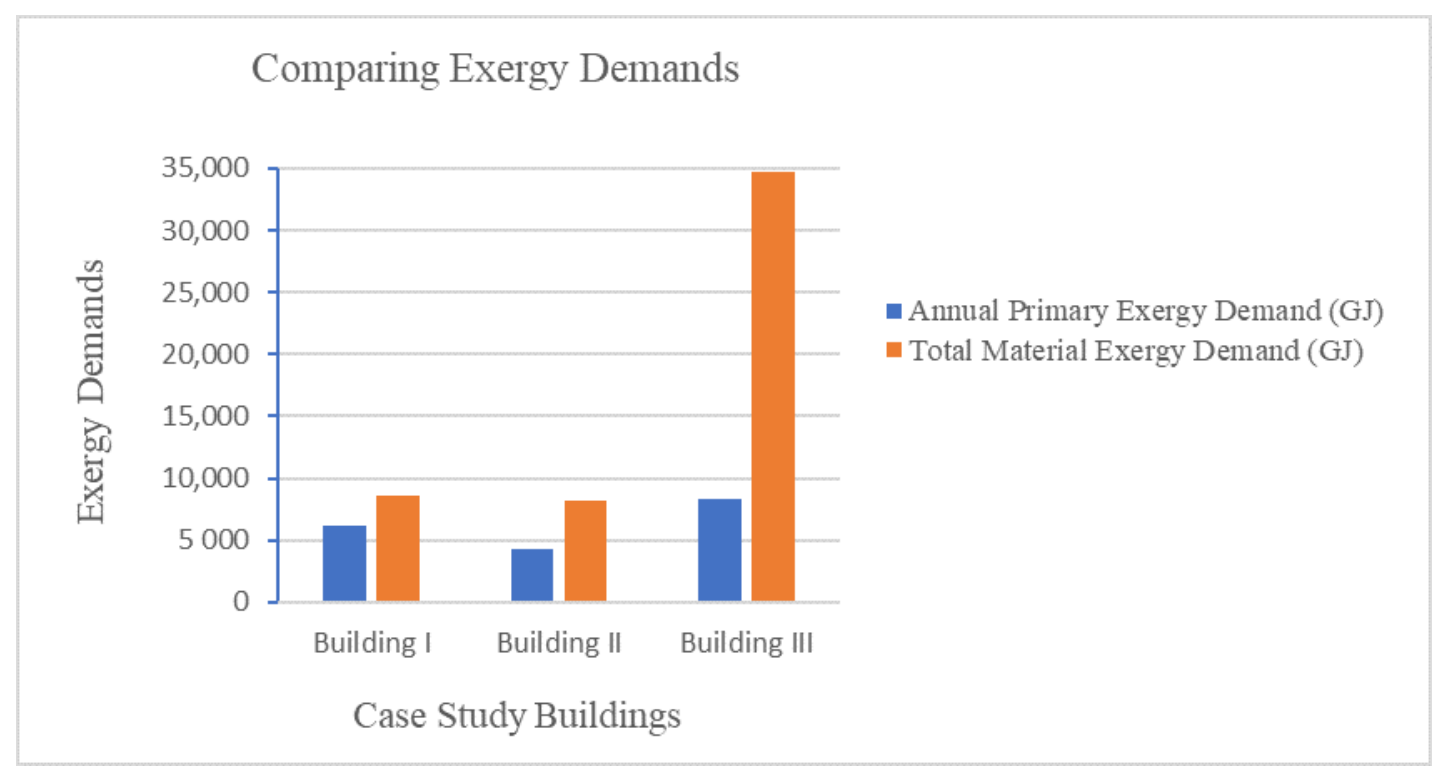

Figure 6. Comparing combined exergy demands between case study buildings.

\section{Discussion}

The results show that the exergy-based LCA method has the potential to solve the characterization and valuation problem seen in the conventional LCA method. The conventional LCA method characterizes environmental impact categories as equivalents to an element or compound, for instance, global warming potential as an equivalent to carbon dioxide emission, or acidification potential as an equivalent to sulfur dioxide emission. With that method of characterization, the impact categories cannot be summed up for an objective comparison between two products or buildings, in this case. So, in conventional LCA, it can be said, for example, that Building $X$ has a higher global warming potential than Building $Y$, and that Building $Y$ has a higher acidification potential than Building $X$. However, it cannot be objectively said that either of the buildings has a higher or lower combined environmental impact potential than the other. The characterization problem, among other challenges in the conventional LCA method, limits its reliability when being applied in policymaking decisions. The exergy-based LCA method presents a paradigm shift in approach, to solve the characterization and valuation problem in a conventional LCA. In Table 2, it can be seen that the environmental impact categories have absolute values and are in single-unit values. The characterization and valuation in an exergybased LCA enable any combination or all of the impact categories to be summed up and compared between products or buildings, as shown in Figure 5 .

Another major benefit of the exergy-based LCA over the conventional LCA is in cases where the data for life-cycle inventory are unavailable, unreliable, or even impractical to obtain. A building's life cycle is one of those cases where energy use and emissions at every stage of the life cycle may be difficult to obtain. The proposed exergy-based LCA method, which can be applied independently, overcomes that difficulty by using the primary exergy demand and material exergy demand. Figures 4 and 6 explore that capacity to respectively compare the material exergy demand and combined exergy demand between the casestudy buildings.

Based on the results and discussion, the appropriateness of the Exe-LCA method was assessed and the benefits are presented in Table 3 as a comparative analysis of the conventional LCA and Exe-LCA of buildings. The benefits included solving major problems in conventional LCAs, such as accuracy, subjectivity in characterization and valuation of results, and potential for practical uses. 
Table 3. Comparative analysis of conventional LCA and exergy-LCA of buildings.

\begin{tabular}{|c|c|c|}
\hline Criteria & Conventional LCA & Exe-LCA \\
\hline Accuracy & Ignores energy quality of fuel source & Considers energy quality of fuel source \\
\hline Comprehensiveness & $\begin{array}{l}\text { Ignores depletion of non-fuel natural } \\
\text { resource }\end{array}$ & $\begin{array}{l}\text { Accounts for the depletion of non-fuel } \\
\text { natural resource }\end{array}$ \\
\hline Interpretation of results & $\begin{array}{l}\text { Difficult to interpret due to variation in } \\
\text { units }\end{array}$ & Uses a unified unit to express its results \\
\hline Subjectivity & More subjective by use of weightings & Less subjective by eliminating weightings \\
\hline Compatibility with other tools & More difficult & Easier as a single objective function \\
\hline Potential for automation & Low & High \\
\hline Priority areas for improvement & More difficult to establish & Easier to establish \\
\hline Use in environmental legislation & $\begin{array}{c}\text { Less useful for objective legislation and } \\
\text { regulation }\end{array}$ & $\begin{array}{c}\text { More useful for objective legislation and } \\
\text { regulation }\end{array}$ \\
\hline Application to industry & Less useful due to high subjectivity & $\begin{array}{c}\text { More useful e.g., in eco-labeling, and } \\
\text { product and process monitoring and } \\
\text { development }\end{array}$ \\
\hline Potential for decision support & Low & High \\
\hline
\end{tabular}

\section{Summary and Conclusions}

The application of an exergy-based LCA method to case-study buildings showed that its theoretical benefits compared to a conventional LCA can be achieved, such as enabling an easier comparison of LCA results between buildings through unifying units, more accurate measurement of energy demand by accounting for energy quality, a more in-depth assessment of resource depletion over a building's life cycle, and solving the problem of characterization in LCA and, thereby, eliminating subjectivity in valuation. The method for the exergy-based LCA of buildings is limited by the available standard chemical exergy values of materials and emissions, as well as by the available gross calorific exergy-toenergy ratios of fuel sources. Future work will explore the validation and encapsulation of the exergy-based LCA method in an automated calculation tool for buildings. The following conclusions are derived from the case studies of the exergy-based life cycle assessment of buildings:

- Unlike the conventional LCA method, the Exe-LCA method expresses environmental impacts as a single objective function, which enables a comparison of the results.

- As opposed to the conventional LCA method, the Exe-LCA method estimates the absolute environmental impact potential.

- The Exe-LCA method evokes a discussion on the accurate interpretation of results of environmental impact assessments.

- The successful application of the Exe-LCA method to the case-study building models showed that its theoretical benefits compared to a conventional LCA can be achieved.

- The results of the Exe-LCA method are in standard metrics, which paves the way for the competitive benchmarking of building sustainability assessments.

Author Contributions: Conceptualization, M.N. and C.J.A.; methodology, M.N.; software, M.N.; validation, M.N. and C.J.A.; formal analysis, M.N.; data curation, M.N.; writing—original draft preparation, M.N.; writing-review and editing, C.J.A.; visualization, M.N.; supervision, C.J.A. All authors have read and agreed to the published version of the manuscript.

Funding: This research did not receive any specific grant from funding agencies in the public, commercial, or not-for-profit sectors.

Institutional Review Board Statement: Not applicable.

Informed Consent Statement: Not applicable.

Data Availability Statement: Not applicable.

Acknowledgments: The authors would like to acknowledge the UF's Planning, Design, and Construction, for providing the energy source and demand data for the case study buildings. The 
authors also acknowledge the Center for Advanced Construction Information Modeling (CACIM) for enabling access to the building information models used for the case study buildings.

Conflicts of Interest: The authors declare no conflict of interest.

\section{Appendix A}

Table A1. Material Exergy Demand for Case Study Building I.

\begin{tabular}{cccc}
\hline Material Name & $\begin{array}{c}\text { Material Mass, MM } \\
(\mathbf{k g})\end{array}$ & $\begin{array}{c}\text { Material Chemical } \\
\text { Exergy (MJ/kg) }\end{array}$ & $\begin{array}{c}\text { Material Exergy } \\
\text { Demand (GJ) }\end{array}$ \\
\hline Aluminum & 49,158 & 29.49 & 1449.669 \\
Brick & 139,125 & 0.18 & 25.043 \\
Ceramic & 2147 & 0.19 & 0.408 \\
Concrete & $1,212,298$ & 0.54 & 654.641 \\
EPDM & 10,867 & 48.04 & 522.051 \\
Epoxy coating & 4201 & 36.18 & 151.992 \\
Fiberglass & 24,265 & 0.59 & 14.316 \\
Glass & 68,163 & 5.20 & 354.448 \\
Gypsum & 126,386 & 0.15 & 18.958 \\
HDPE & 1051 & 48.50 & 50.974 \\
Hollow core/mortar & 137,962 & 0.40 & 55.185 \\
Paint (acrylic) & 4843 & 39.30 & 190.330 \\
Paint (silicone) & 11,790 & 39.28 & 463.111 \\
Polyurethane foam & 5848 & 36.61 & 214.095 \\
Steel & 110,474 & 34.64 & 3826.819 \\
Wallpaper & 324 & 70.53 & 22.852 \\
Wood & 20,016 & 31.23 & 625.100 \\
\hline
\end{tabular}

\section{Appendix B}

Table A2. Material Exergy Demand for Case Study Building II.

\begin{tabular}{cccc}
\hline Material Name & $\begin{array}{c}\text { Material Mass, MM } \\
(\mathbf{k g})\end{array}$ & $\begin{array}{c}\text { Material Chemical } \\
\text { Exergy (MJ/kg) }\end{array}$ & $\begin{array}{c}\text { Material Exergy } \\
\text { Demand, MExD (GJ) }\end{array}$ \\
\hline Aluminum & 7299 & 29.49 & 215.248 \\
Brick & 452,569 & 0.18 & 81.462 \\
Carpet & 44,234 & 45.31 & 2004.243 \\
Ceramic & 5235 & 0.19 & 0.995 \\
Concrete & $2,927,124$ & 0.54 & 1580.647 \\
EPDM & 9208 & 48.04 & 442.352 \\
Fiberglass & 26,667 & 0.59 & 15.734 \\
Glass & 15,500 & 5.20 & 80.600 \\
Gypsum & 100,597 & 0.15 & 15.090 \\
Hollow core/mortar & 48,219 & 0.40 & 19.288 \\
Paint (silicone) & 12,484 & 39.28 & 490.372 \\
Plastic (PVC) & 1234 & 22.25 & 27.457 \\
Polyurethane foam & 7603 & 36.61 & 278.346 \\
Steel & 86,130 & 34.64 & 2983.543 \\
\hline
\end{tabular}




\section{Appendix C}

Table A3. Material Exergy Demand for Case Study Building III.

\begin{tabular}{cccc}
\hline Material Name & Material Mass (kg) & $\begin{array}{c}\text { Material Chemical } \\
\text { Exergy (MJ/kg) }\end{array}$ & $\begin{array}{c}\text { Material Exergy } \\
\text { Demand (MJ) }\end{array}$ \\
\hline Aluminum & 36,806 & 29.49 & 1085.409 \\
Brick & 571,606 & 0.18 & 102.889 \\
Concrete & $6,931,514$ & 0.54 & 3743.018 \\
EPDM & 28,162 & 48.04 & 1352.902 \\
Glass & 34,953 & 5.20 & 181.756 \\
Gypsum & 33,059 & 0.15 & 4.959 \\
Hollow core/mortar & 870,441 & 0.40 & 348.176 \\
Paint (acrylic) & 8376 & 39.30 & 329.177 \\
Paint (silicone) & 4203 & 39.28 & 165.094 \\
Polyurethane foam & 3735 & 36.61 & 136.738 \\
Steel & 787,632 & 34.64 & $27,283.572$ \\
Wood & 213 & 31.23 & 6.652 \\
\hline
\end{tabular}

\section{References}

1. World Energy Statistics and Balances. Available online: https://www.iea.org/topics/energyefficiency/buildings / (accessed on 20 September 2021).

2. Hauschild, M.Z.; Rosenbaum, R.K.; Olsen, S.I. (Eds.) Life Cycle Assessment-Theory and Practice; Springer: Berlin/Heidelberg, Germany, 2018. [CrossRef]

3. Alshamrani, O.S.; Galal, K.; Alkass, S. Integrated LCA-LEED sustainability assessment model for structure and envelope systems of school buildings. Build. Env. 2014, 80, 61-70. [CrossRef]

4. Simonen, K. Life Cycle Assessment, 1st ed.; Routledge: New York, USA, 2014.

5. Nwodo, M.N.; Anumba, C.J. A review of life cycle assessment of buildings using a systematic approach. Build. Env. 2019, 162, 106290. [CrossRef]

6. Finnveden, G.; Arushanyan, Y.; Brandão, M. Exergy as a measure of resource use in life cycle assessment and other sustainability assessment tools. Resources 2016, 5, 23. [CrossRef]

7. Morosuk, T.; Tsatsaronis, G.; Koroneos, C. Environmental impact reduction using exergy based methods. J. Clean. Prod. 2016, 118, 118-123. [CrossRef]

8. Wang, Q.; Ma, Y.; Li, S.; Hou, J.; Shi, J. Exergetic life cycle assessment of Fushun type shale oil production process. Energy Convers. Manag. 2018, 164, 508-517. [CrossRef]

9. Rosen, M. Energy sustainability: A pragmatic approach and illustrations. Sustainability 2009, 1, 55-80. [CrossRef]

10. Fiaschi, D.; Manfrida, G.; Mendecka, B.; Tosti, L.; Parisi, M.L. A comparison of different approaches for assessing energy outputs of combined heat and power geothermal plants. Sustainability 2021, 13, 4527. [CrossRef]

11. Gaudreau, K.; Fraser, R.A.; Murphy, S. The tenuous use of exergy as a measure of resource value or waste impact. Sustainability 2009, 1, 1444-1463. [CrossRef]

12. Srinivasan, R.; Moe, K. The Hierarchy of Energy in Architecture: Emergy Analysis, 1st ed.; Routledge: New York, USA, 2015.

13. Shukuya, M.; Hammache, A. Introduction to the concept of exergy-for a better understanding of low-temperature-heating and high-temperature-cooling systems. VTT Tiedotteita. 2002. Research Notes, no. 2158, VTT Technical Research Centre of Finland, Espoo.. Available online: http:/ / www.vtt.fi/inf/pdf/tiedotteet/2002/T2158.pdf (accessed on 19 October 2021).

14. Bastianoni, S.; Facchini, A.; Susani, L.; Tiezzi, E. Emergy as a function of exergy. Energy 2007, 32, 1158-1162. [CrossRef]

15. Guinee, J.B.; Heijungs, R.; Huppes, G.; Zamagni, A.; Masoni, P.; Buonamici, R.; Ekvall, T.; Rydberg, T. Life cycle assessment: Past, present, and future. Environ. Sci. Technol. 2011, 45, 90-96. [CrossRef]

16. De Meester, B.; Dewulf, J.; Verbeke, S.; Janssens, A.; Van Langenhove, H. Exergetic life-cycle assessment (ELCA) for resource consumption evaluation in the built environment. Build. Environ. 2009, 44, 11-17. [CrossRef]

17. Nwodo, M.N.; Anumba, C.J. Exergetic life cycle assessment: A review. Energies 2020, 13, 2684. [CrossRef]

18. AZOCleanTech. An Introduction to Exergy. Interview Conducted by PROFESSOR Ibrahim Dincer on 22 July 2013. Available online: https: / / www.azocleantech.com/article.aspx?ArticleID=426 (accessed on 20 September 2021).

19. Švajlenka, J.; Kozlovská, M.; Pošiváková, T. Analysis of selected building constructions used in industrial construction in terms of sustainability benefits. Sustainability 2018, 10, 4394. [CrossRef]

20. Mora, T.D.; Bolzonello, E.; Cavalliere, C.; Peron, F. Key parameters featuring BIM-LCA integration in buildings: A practical review of the current trends. Sustainability 2020, 12, 7182. [CrossRef]

21. Carvalho, J.P.; Alecrim, I.; Bragança, L.; Mateus, R. Integrating BIM-Based LCA and building sustainability assessment. Sustainability 2020, 12, 7468. [CrossRef] 
22. Cheng, B.; Li, J.; Tam, V.W.Y.; Yang, M.; Chen, D. A BIM-LCA approach for estimating the greenhouse gas emissions of large-scale public buildings: A case study. Sustainability 2020, 12, 685. [CrossRef]

23. Palumbo, E.; Soust-Verdaguer, B.; Llatas, C.; Traverso, M. How to obtain accurate environmental impacts at early design stages in BIM when using environmental product declaration. A method to support decision-making. Sustainability 2020, $12,6927$. [CrossRef]

24. Horn, R.; Ebertshäuser, S.; Bari, R.D.; Jorgji, O.; Traunspurger, R.; von Both, P. The BIM2LCA Approach: An Industry foundation classes (IFC)-Based interface to integrate life cycle assessment in integral planning. Sustainability 2020, 12, 6558. [CrossRef]

25. Theißen, S.; Höper, J.; Drzymalla, J.; Wimmer, R.; Markova, S.; Meins-Becker, A.; Lambertz, M. Using open BIM and IFC to enable a comprehensive consideration of building services within a whole-building LCA. Sustainability 2020, 12, 5644. [CrossRef]

26. Allan, K.; Phillips, A.R. Comparative Cradle-to-Grave Life Cycle assessment of low and mid-rise mass timber buildings with equivalent structural steel alternatives. Sustainability 2021, 13, 3401. [CrossRef]

27. Szargut, J.; Morris, D.R.; Steward, F.R. Exergy Analysis of Thermal, Chemical, and Metallurgical Processes; Hemisphere Publishing: New York, NY, USA, 1988.

28. Dewulf, J.; Van Langenhove, H.; Muys, B.; Bruers, S.; Bakshi, B.R.; Grubb, G.F.; Paulus, D.M.; Sciubba, E. Exergy: Its potential and limitations in environmental science and technology. Environ. Sci. Technol. 2008, 42, 2221-2232. [CrossRef] [PubMed]

29. Dixit, M.K.; Culp, C.H.; Fernandez-Solis, J.L. Calculating primary energy and carbon emission factors for the United States' energy sectors. RSC Adv. 2014, 4, 54200-54216. [CrossRef]

30. Wang, W.; Zmeureanu, R.; Rivard, H. Applying multi-objective genetic algorithms in green building design optimization. Build. Environ. 2005, 40, 1512-1525. [CrossRef]

31. Bailey, R.G. Understanding Regional Ecosystem Patterns to Design Monitoring Networks and Sustainable Landscapes. In Proceedings of the Monitoring Science and Technology Symposium, Denver, CO, USA, 20-24 September 2004.

32. Szargut, J.; Morris, D.R. Cumulative exergy consumption and cumulative degree of perfection of chemical processes. Int. J. energy Res. 1987, 11, 245-261. [CrossRef]

33. Zhang, M. Analysis of Energy Conversion Systems, Including Material and Global Warming Aspects. Doctoral Dissertation, Oregon State University, Corvallis OR, USA, 1995. Available online: https://ir.library.oregonstate.edu/concern/graduate_thesis_ or_dissertations/kw52jc36k (accessed on 19 October 2021). 